\title{
Genetic testing in Europe: transborder testing is a necessity
}

\author{
Mariana Jovanovic ${ }^{1 *}$, Els Dequeker ${ }^{2}$, Lieve Desmet ${ }^{2}$, Michael Morris $^{3}$, Jean-Jacques Cassiman ${ }^{2}$, Ségolène Aymé ${ }^{1}$ \\ From 5th European Conference on Rare Diseases (ECRD 2010) \\ Krakow, Poland. 13-15 May 2010
}

Genetic tests are now offered internationally, through both public and private sector genetic testing services. Physicians prescribing these tests and biologists receiving the samples need to know which tests are available, where they are performed and whether the identified laboratories meet quality standards. To fulfil this need, http://www.orpha.net was launched thirteen years ago to set up a database of clinical laboratories in the field of rare diseases. Data was collected in 1 country in 1997, 15 in 2003, 26 in 2006 and 38 in 2010. This major effort was made possible thanks to resources from the EC DG for Public Health. In collaboration with the EuroGentest Network of Excellence, information on quality management has been added to the Orphanet database over the past four years. To obtain information on genetic testing in Orphanet, it is possible to search by disease name or by gene (symbol or name in English) in addition to the traditional search by name of laboratory or professional. The information provided on laboratories includes data on quality management. Currently, 956 laboratories offering tests for 1,559 genes are registered in the Orphanet database. The test offer differs greatly from one large country to another: Germany (1,141 genes), France (874 genes), Italy (625 genes), Spain (582 genes), UK (414 genes). Medium and small-sized countries have a test offer ranging from 1 to 233 genes. This situation explains the large cross-border flow of specimens and underlines the need to provide access to services in other countries when necessary, especially for very rare diseases. Testing for Cystic fibrosis is the only service which is provided by every country. The distribution of this test offer will be presented.

*Correspondence: mariana.jovanovic@inserm.fr

'Orphanet, Plateforme Maladies Rares, 96 rue Didot, 75014 Paris, France

Full list of author information is available at the end of the article

\section{Author details}

'Orphanet, Plateforme Maladies Rares, 96 rue Didot, 75014 Paris, France. ${ }^{2}$ Eurogentest, University of Leuven, Centre for Human Genetics, Herestraat 49, Box 602, 3000 Leuven, Belgium. ' ${ }^{3}$ aboratoire de Diagnostic Molculaire, Service de Génétique Médicale, CMU Rue Michel Servet 1, 1211 Genève, Switzerland.

Published: 19 October 2010

\section{doi:10.1186/1750-1172-5-S1-P4}

Cite this article as: Jovanovic et al.: Genetic testing in Europe: transborder testing is a necessity. Orphanet Journal of Rare Diseases 2010 5(Suppl 1):P4.

\section{Submit your next manuscript to BioMed Central and take full advantage of: \\ - Convenient online submission \\ - Thorough peer review \\ - No space constraints or color figure charges \\ - Immediate publication on acceptance \\ - Inclusion in PubMed, CAS, Scopus and Google Scholar \\ - Research which is freely available for redistribution

